\title{
Anti-tumor Properties of Prunella vulgaris
}

\author{
Mofei Huang ${ }^{1,2} \cdot$ Yian Wang ${ }^{2} \cdot \operatorname{Ling} \mathrm{Xu}^{1} \cdot$ Ming You $^{2}$
}

Published online: 15 May 2015

(C) Springer International Publishing AG 2015

\begin{abstract}
Cancer is one of the most serious threats to public health around the world. Efforts in developing new therapies and prevention strategies are clearly insufficient in the face of a dramatically rising disease burden worldwide. New evaluation of alternate strategies, including those based on traditional medicine, is increasingly needed. These therapeutic or prevention approaches could prove complementary to current medical practice or could potentially aid in the development of new classes of pharmaceutical drugs with anti-cancer properties. Prunella vulgaris, a perennial herb, is a representative Chinese herb that has been put into practice to treat various types of diseases, including cancer. The triterpenoid, flavonoids, and phenylpropanoids in P. vulgaris have shown a collective therapeutic effect against cancer mediated through multiple pathways. This review discusses the chemical constituents of $P$. vulgaris, summarizes all of the known formulas that contain $P$. vulgaris, and also discusses in vitro, in vivo, and clinical studies on the anti-tumor properties of $P$. vulgaris. The aim is to bring better insights regarding $P$. vulgaris as an effective complementary method for treating cancer. Highlighted throughout
\end{abstract}

This article is part of the Topical Collection on Cancer Chemoprevention

This work was supported by Longhua Medical Project, No. LYTD-24 (You)

Ming You

myou@mcw.edu

1 Longhua Hospital, Shanghai University of Traditional Chinese Medicine, 725 South Wanping Rd., Shanghai 200032, China

2 Medical College of Wisconsin Cancer Center and Department of Pharmacology and Toxicology, Medical College of Wisconsin, 8701 Watertown Plank Road, Milwaukee, WI 53226, USA this review is the necessity for additional prospective clinical trials on anti-tumor properties of $P$. vulgaris.

Keywords Prunella vulgaris · Chinese herbs · Cancer . Chemoprevention

$\begin{array}{ll}\text { Abbreviations } & \\ \text { PV } & \text { Prunella vulgaris } \\ \text { HUVEC } & \text { Human umbilical vein endothelial cell } \\ \text { PVAE } & \text { Aqueous extract isolated from } \\ & \text { Prunella vulgaris } \\ \text { EESP } & \text { Ethanol extract of Spica prunella } \\ \text { RA } & \text { Rosmarinic acid } \\ \text { ROS } & \text { Reactive oxygen species } \\ \text { OA } & \text { Oleanolic acid } \\ \text { UA } & \text { Ursolic acid } \\ \text { MAPK/ERK } & \text { Mitogen-activated protein } \\ & \text { kinases/extracellular signal-regulated kinase } \\ \text { NSCLC } & \text { Non-small cell lung cancer } \\ \text { TRAIL } & \text { Tumor necrosis factor-related } \\ & \text { apoptosis-inducing ligand } \\ \text { FASN } & \text { Fatty acid synthase } \\ \text { EPVL } & \text { Extract of Prunella vulgaris L } \\ \text { IR } & \text { Inhibitory rate } \\ \text { DMH } & \text { 1,2-Dimethylhydrazine } \\ \text { ACF } & \text { Aberrant crypt foci } \\ \text { FLT } & \text { Flourothymidine } \\ \text { P 60 } & \text { 60\% ethanol extract of PV } \\ \text { CTX } & \text { Cyclophosphamide } \\ \text { GR } & \text { Gastrointestinal reaction } \\ \text { BMS } & \text { Bone marrow suppression } \\ \text { ALT } & \text { Alanine aminotransferase } \\ \text { 4NQO } & \text { 4-nitroquinoline-1-oxide } \\ \text { ATB } & \text { Anti-tumor B } \\ & \end{array}$




\section{Introduction}

Traditional Chinese medicine (TCM) is often considered as complementary to Western medicine in treating various types of cancer. It is a major part of the use of botanical medicine that is widespread in all regions of developing world and is consistently growing in popularity in industrialized countries, especially among patients diagnosed with cancer [1]. Prunella vulgaris, a perennial herb, grows natively across East Asia throughout China, Japan, Korea, and Europe. It is commonly used as a dietary supplement [2]. As a folk medicine used for thousands of years in China, it has been mainly used as an antipyretic remedy for alleviating sore throat, reducing fever, and accelerating wound healing $[3,4 \bullet]$. Its major bioactive ingredients consist of triterpenoids, steroids, flavonoids, coumarins, organic acid, volatile oil, phenylpropanoids, and carbohydrate [5]. Most of these substances have been shown a wide spectrum of biological properties including anti-viral [6, 7], anti-oxidant [8,9], anti-microbial [10, 11], antiinflammatory $[12,13]$, anti-diabetic $[14,15]$, antiestrogenic [16], anti-allergic [17], immune modulatory $[18,19]$, and anti-cancer $[20,21]$ effects. In China, this well-known traditional herb is used as the key ingredient in many Chinese herbal mixtures in the forms of decoction, capsule, granule, or infusion for treatment of cancer, primarily as an adjuvant/complementary treatment in the majority of patients (see Table 1).

Of these formulas containing P. vulgaris, anti-tumor-B (ATB) have shown strong cancer chemopreventive activities both preclinically and in clinical trials. In a clinical study [56], a total of 449 patients with esophageal epithelial hyperplasia were randomly divided into an anti-tumor B treatment $(n=300)$ and a placebo control group $(n=149)$. After 6 months of oral administration, the response rate of the ATB group was 64.4 vs $22.8 \%$ compared to placebo group $(p<0.001)$ and the frequency of progression was 3.3 and $24.8 \%(p<0.001)$, respectively. In a 4nitroquinoline-1-oxide (4NQO) induced oral squamous cell carcinoma model in A/J mice [55], ATB inhibited tumor development by $59.2 \%$. ATB treatment resulted in a significant reduction in multiplicity and tumor load in a $\mathrm{A} / \mathrm{J}$ mutant lung adenocarcinoma model [57]. ATB inhibited the incidence of bladder cancer by $90.7 \%$ $(p<0.01)$ in a rat bladder cancer model treated with $\mathrm{N}$ butyl-(4-hydroxybutyl) nitrosamide (BBN) [58]. In general, ATB has been shown to be a potent cancer chemopreventive agent. However, it is still not clear if P. vulgaris is responsible for the observed chemopreventive efficacy of ATB or in any other Chinese herbal mixtures containing $P$. vulgaris. Future studies should focus on the role $P$. vulgaris in ATB's efficacy as well as its chemopreventive effects as a single agent.

\section{Chemical Constituents of $P$. vulgaris}

P. vulgaris contains nine categories of chemical compounds isolated by various methods (listed in Tables 2 and 3). Four of the nine structural categories, namely, triterpenoid, flavonoid, phenylpropanoids, and steroids are found to have strong antitumor properties. Among these, triterpenoids have been the most widely investigated probably due to its high content in $P$. vulgaris. Kyun Lee et al. [94] isolated fifteen triterpenoids through the method of methanol extraction of $P$. vulgaris. Of the extracted triterpenoids, ursolic acid and oleanic acid are the two key constituents [59] that have shown anti-cancer properties (Tables 2 and 3). Ursolic acid [95] has anti-cancer effects against gallbladder cancer through suppression of proliferation, cell cycle arrest, and increased tumor cell apoptosis. Two new triterpenoids, pentacyclic triterpenoid [96] glycosides Vulgasides I and II have recently been isolated from P. vulgaris. The amount of flavonoid [97] was $2.2-10.3 \%$ in $P$. vulgaris. Other phytochemicals, such as rutin, quercetin, and hyperoside, are found to have anti-cancer properties, including anti-proliferation, immune-enhancing, anti-oxidant, pro-apoptosis, cell cycle arrest in in vivo or in vitro studies. Phenolic acids consisting of rosmarinic acid and caffeic acid may also play a role in the anti-tumor properties of $P$. vulgaris through the mechanism of anti-angiogenesis, anti-proliferation, and induction on apoptosis. In the 7,12dimethylbenz[a]anthracene (DMBA) induced skin tumor model using Swiss albino mice [88], oral administration of rosmarinic acid completely prevented the formation of skin tumors. Finally, five additional categories of chemical compounds are steroid, coumarins, organic oils, carbohydrates, and volatile oils. Steroid category [59] extracts include $\beta$-sitosterol, stigmasterol, and $\alpha$-spinasterol.

\section{In Vitro Anti-cancer Activity (Table 3)}

\section{Anti-proliferation}

Several studies $[67,71,98-109]$ revealed that $P$. vulgaris inhibits the proliferation of human cancer cell lines (Table 3), including human esophageal cancer cell line Eca 109 [110, 111], liver cancer cell line $\mathrm{HepG}_{2}$, cervical cancer Hela cell, and stomach cancer MKN 45 cell line [8]. Possible mechanisms suggested include the inhibition of the c-Jun N-terminal kinase $(\mathrm{JNK})$ pathway $[1,2]$ and the Akt pathway $[2,3]$. Ethanol extract of $P$. vulgaris was found to inhibit colon cancer cell line HT-29 by arresting the cell cycle at the G1/S checkpoint and reducing the expression of pro-proliferative cyclin D1 and cyclin-dependent kinase 4 (CDK4) at the transcriptional and translational level [108]. P. vulgaris has also been shown to have combinatorial effects with other agents. For example, $P$. vulgaris extracts enhanced the effects of 


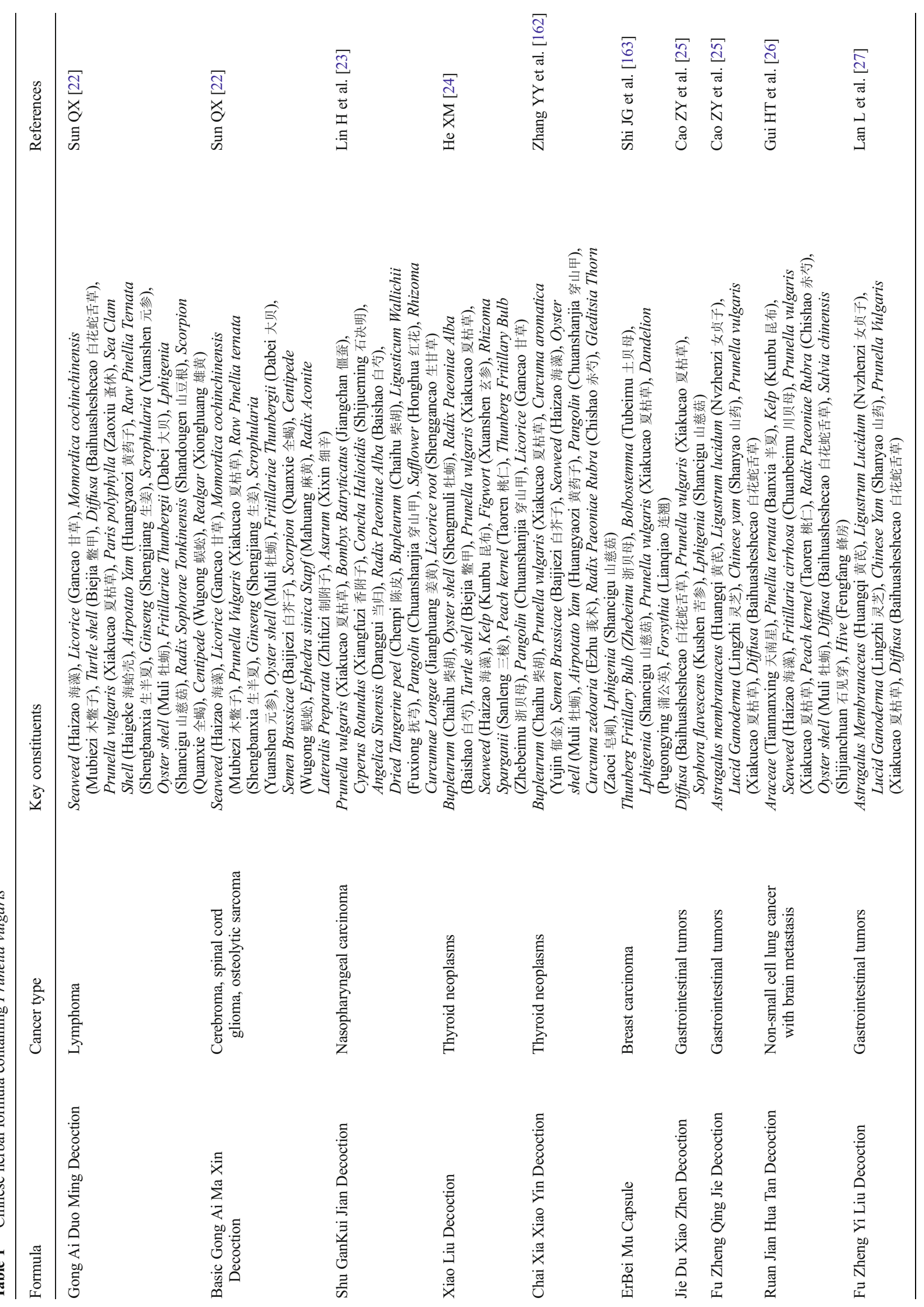




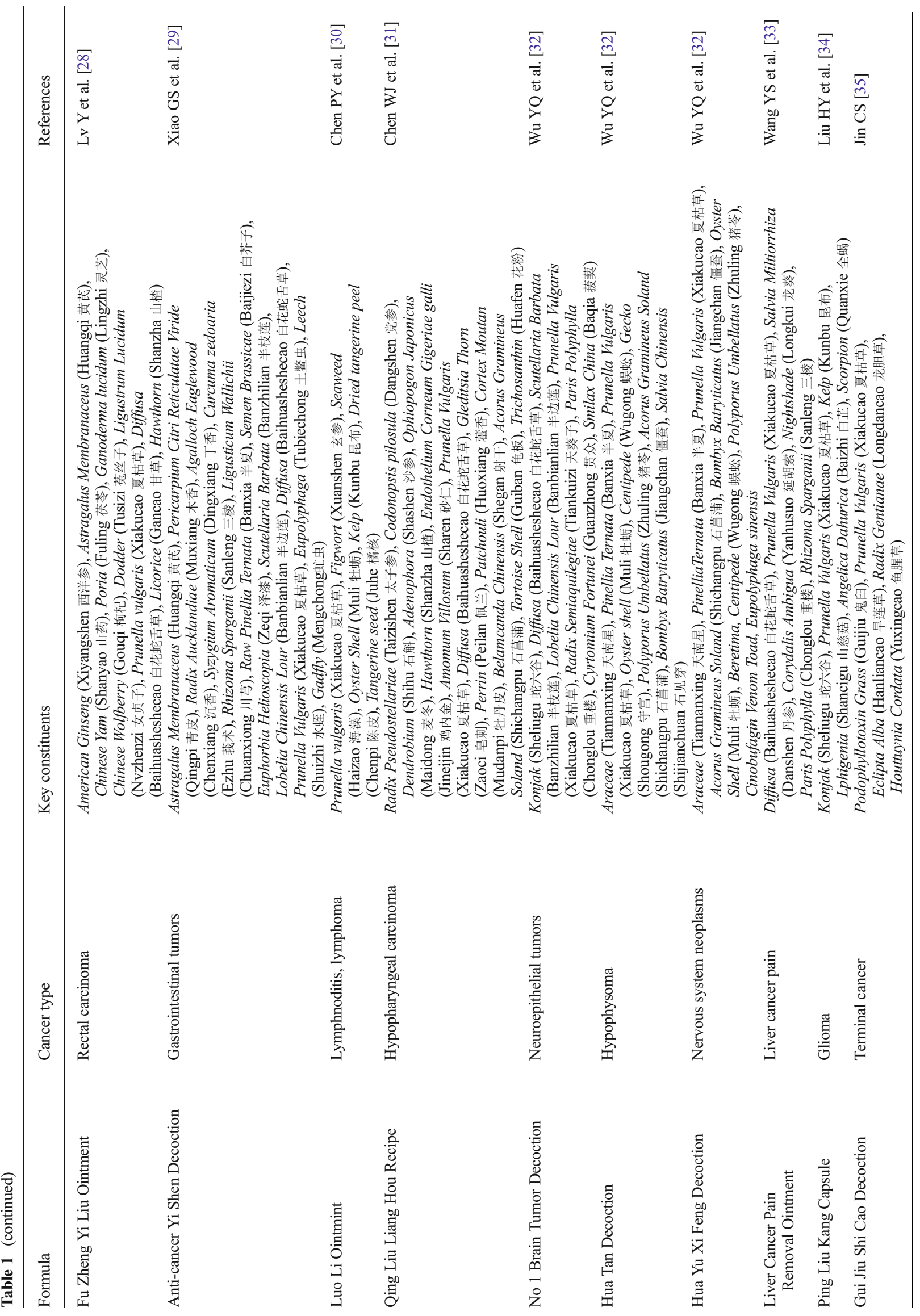




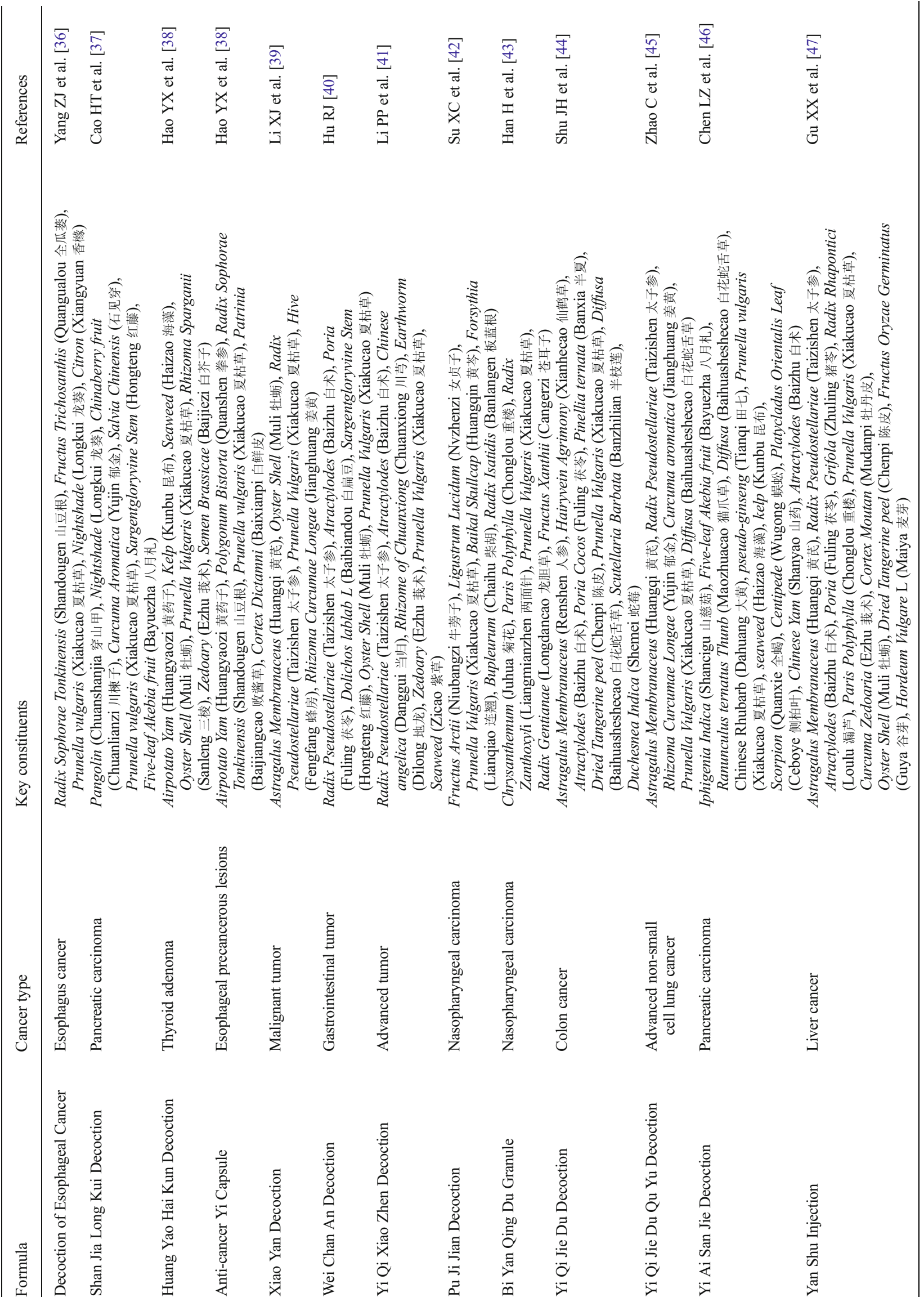




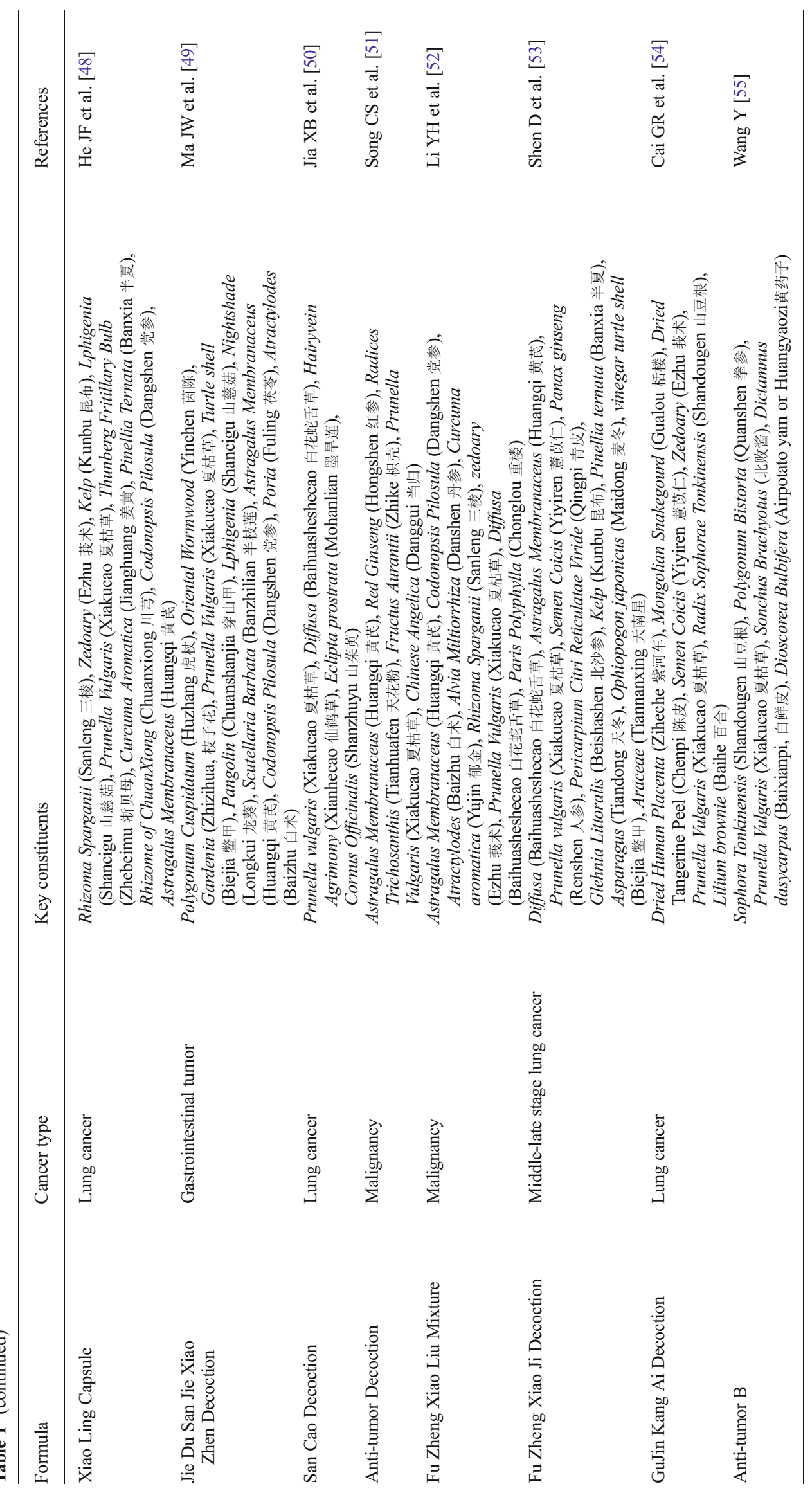


Table 2 Key ingredients contained in Prunella vulgaris

\begin{tabular}{|c|c|c|}
\hline Types & Nutrient ingredients & References \\
\hline Triterpenoid & 28 kinds of triterpenoid with ursolic acid and oleanic acid highest in quantity & {$[5,59,60]$} \\
\hline Steroids & $\begin{array}{l}\text { B-sitosterol, stigmasterol, } \alpha \text {-spinasterol, stigmast-7-en-3 } \beta \text {-ol,(22E,20S,24S)-stigmastra-7, } \\
\text { 22-dien-3-one,daucosteol }\end{array}$ & \\
\hline Flavonoids & $\begin{array}{l}\text { Rutin, lutiolin, homoorientin, cinaroside, quercetin, quercetin-3-O- } \beta \text {-D-galatoside, } \\
\text { quercetin-3-O- } \beta \text {-D-glucoside, kaempferol-3-O- } \beta \text {-D-glucoside }\end{array}$ & \\
\hline Coumarins & Umbelliferone, scopoletin, esculetin & \\
\hline Organic acid & $\begin{array}{l}\text { cis- and trans-caffeic acid, palmitic acid, stearic acid, 6,9-otodecadienoic acid, 3,6,17-eicosatrienoic acid, } \\
\text { oleic acid, arachidic acid, behemic acid, lauric acid, myristic acid, linoleinic acid }\end{array}$ & \\
\hline Carbohydrate & Monosaccharide, disaccharide, polysaccharide & \\
\hline Volatile oil & 1,8-Eucalyptol, pinene, myrcene, linalyl acetate, $\alpha$-phellandrene, linalool & \\
\hline Phenylpropanoids & $\begin{array}{l}\text { cis-and-trans-caffeic acid, rosmarinic acid, methyl rosemarinicine, } \\
\text { ethyl rosemarinicine, } 3,4, \alpha-3 \text { hydroxyl-methyl-phenyl propionate }\end{array}$ & \\
\hline Others & $d$-camphor, $d$-fenchone, carotene, vitamin $\mathrm{B}$, vitamin $\mathrm{C}$, vitamin $\mathrm{K}$, resin, tannin, alkaloid, water soluble salt & \\
\hline
\end{tabular}

paclitaxel (TAX) and adriamycin (ADM) on inhibiting cell growth of cancer cells [105]. A combination of $P$. vulgaris and Cremastra appendiculata exhibited an enhanced effects in inhibiting the growth of thyroid cancer cell line $[112,113]$, along with down-regulation of the c-myc expression.

In addition to $P$. vulgaris extracts, some of its ingredients have also been examined for anti-cancer activities (Table 3). Triterpenoicacids, a component of P. vulgaris [94, 106, 107], exhibited strong cytotoxic activity against human lung cancer cell line A459. Triterpenoic acid [94] isolated from P. vulgaris has been shown to inhibit cell growths of various human cancer cell lines, namely, A549 cell lines, SK-OV-3 (ovarian cancer cell), SK-MEL-2 (skin melanoma), and HCT 15 (colon cancer cell). Ursolic acid [67], one of the most abundant triterpenoic acids in $P$. vulgaris, showed inhibitory effect on colon cancer cell lines HCT-15 and DLD-1. The mechanism [67] underlying ursolic acid-mediated anti-proliferation against human colon cancer cell lines is believed to be related to the N-terminal phosphorylation and subsequent proteasomal degradation of $\beta$-catenin. Ursolic acid also reduced proliferation in many other tumor cell lines, like human leukemic cell line HL-60 [114], mouse melanoma cell line B16 [115], human breast MCF7 [116]. Oleanic acid, an active component of P. vulgaris [71], inhibited the proliferation of HT-29 cells in dose-dependent manner through the mechanism of G0/G1 checkpoint arrest. Oleanolic acid [70] also exhibited strong anti-proliferation activity against human lung SPC-A-1 cells. Interestingly, an endophytic fungus CPCC 480171 [117] isolated from P. vulgaris was found to have cytotoxic effects on multiple human cell line, A549 (lung cancer), LOVO cells (colon cancer), CEM cells (T cell leukemia), and HL-60 (leukemia). Caffeic acid, a major phenolic compound in P. vulgaris [93], was observed to inhibit cancer cell proliferation, especially at a high concentration (over $30 \mu \mathrm{g} / \mathrm{ml}$ ). Table 4 summarized in vitro efficacy of $P$. vulgaris and its extracts or components against cancer cell lines.

\section{Regulation of Cell Cycle Progression and Cell Cycle Arrest}

P. vulgaris has been shown to induce cell cycle arrest at various checkpoints in cancer cells. After thyroid carcinoma cell line SW579 [109] was treated with P. vulgaris, the proportion of cells in the $\mathrm{S}$ phase was observed to be reduced, while those in the G0/G1 phase was significantly increased when compared to the control group. In another study [108], the ethanol extract of $P$. vulgaris arrested cells at the G1/S checkpoint in human colon carcinoma cells and inhibited the expression of both cyclin D1 and CDK4. Rutin [83], one of the flavonoids from $P$. vulgaris, showed anti-tumor effect against human neuroblastoma LAN- 5 cells by inducing G2/M cell cycle arrest and apoptosis. Ursolic acid, another component of P. vulgaris, was shown to block B16 mouse melanoma cell line in G1 phase [115]. These reports suggest that $P$. vulgaris is capable of inducing cell cycle arrest in various cancer cell lines.

\section{Induction of Apoptosis}

Apoptosis [143-148] has been shown to be induced by many anti-tumor regimens [145-148] such as chemotherapy, radiation as well as Chinese herbs such as $P$. vulgaris. P. vulgaris and its components have been shown to induce apoptosis in a variety of cancer cell lines (including Raji cells [1, 4•], SGC7901 [119], SW 579 [109, 112], Eca 109 [111], EL-4 [121], Jurket cells [103, 104], PANC-1 [122], T24 [136], HepG2, HT29, A549, MKN-45, and Hela cells [8]). Several phytochemicals from $P$. vulgaris including oleanic acid [70], ursolic acid [65], rosmarinic acid [126], and caffeic acid [93] have also been shown to either induce or promote apoptosis in cancer cells. Mechanisms suggested by several studies are both the up-regulation of the expression of p53 [65], Bax [8, 64, 70, 101, 104, 111, 122], Fas [136], Bad [70], caspase 3 
Table 3 Chemical structures of the major anti-cancer chemical compounds in Prunella vulgaris

\begin{tabular}{|c|c|c|c|c|c|}
\hline Classification & Compound & $\begin{array}{l}\text { Molecular } \\
\text { formula }\end{array}$ & $\begin{array}{l}\text { Chemical } \\
\text { structure }\end{array}$ & MW & Effect and references \\
\hline \multirow[t]{2}{*}{ Triterpenoid } & Ursolic acid & $\mathrm{C}_{30} \mathrm{H}_{48} \mathrm{O}_{3}$ & & 456.70 & $\begin{array}{l}\text { Anti-oxidant [61], cell cycle } \\
\text { arrest [62], immune- } \\
\text { enhancing [63], induction on } \\
\text { apoptosis }[64,65] \quad \text { and } \\
\text { differentiation [66], anti- } \\
\text { proliferation [67] }\end{array}$ \\
\hline & Oleanic acid & $\mathrm{C}_{30} \mathrm{H}_{48} \mathrm{O}_{3}$ & & 456.70 & $\begin{array}{lr}\text { Anti-oxidant [68], cell } & \text { cycle } \\
\text { arrest [69], induction } & \text { on } \\
\text { apoptosis [70], } & \text { anti- } \\
\text { proliferation [71], } & \text { and } \\
\text { suppression on migration and } \\
\text { metastasis [72] }\end{array}$ \\
\hline \multirow[t]{4}{*}{ Flavonoid } & Luteolin & $\mathrm{C}_{15} \mathrm{H}_{10} \mathrm{O}_{6}$ & & 286.24 & $\begin{array}{l}\text { Enhancing sensitivity of } \\
\text { chemotherapy }[73] \text {, cell cycle } \\
\text { arrest }[74] \text {, apoptosis }[75,76]\end{array}$ \\
\hline & Quercetin & $\mathrm{C}_{15} \mathrm{H}_{10} \mathrm{O}_{7}$ & & 302.24 & $\begin{array}{l}\text { Anti-oxidant [77], cell cycle } \\
\text { arrest [78], induction on } \\
\text { apoptosis [79], } \\
\text { proliferation [80], }\end{array}$ \\
\hline & Rutin & $\mathrm{C}_{27} \mathrm{H}_{30} \mathrm{O}_{16}$ & & 610.52 & $\begin{array}{l}\text { cytotoxic effect [81], immune- } \\
\text { enhancing [82], anti- } \\
\text { proliferation [83], Anti-oxidant [84] }\end{array}$ \\
\hline & Hyperoside & $\mathrm{C}_{21} \mathrm{H}_{20} \mathrm{O}_{12}$ & & 464.38 & $\begin{array}{l}\text { Anti-proliferation [85], } \\
\text { apoptosis [86], Anti-oxidant [87 }\end{array}$ \\
\hline \multirow[t]{2}{*}{ Phenylpropanoid } & $\begin{array}{l}\text { Rosmarinic } \\
\text { acid }\end{array}$ & $\mathrm{C}_{18} \mathrm{H}_{16} \mathrm{O}_{8}$ & & 360.31 & $\begin{array}{l}\text { Induction on apoptosis [88], anti- } \\
\text { angiogenesis [89], } \\
\begin{array}{l}\text { proliferation }[90,91], \\
\text { chemoprevention [92] }\end{array}\end{array}$ \\
\hline & $\begin{array}{l}\text { Caffeic } \\
\text { acid }\end{array}$ & $\mathrm{C}_{9} \mathrm{H}_{8} \mathrm{O}_{4}$ & & 180.16 & $\begin{array}{l}\text { Anti-proliferation [73], and } \\
\text { induction on apoptosis [93] }\end{array}$ \\
\hline
\end{tabular}




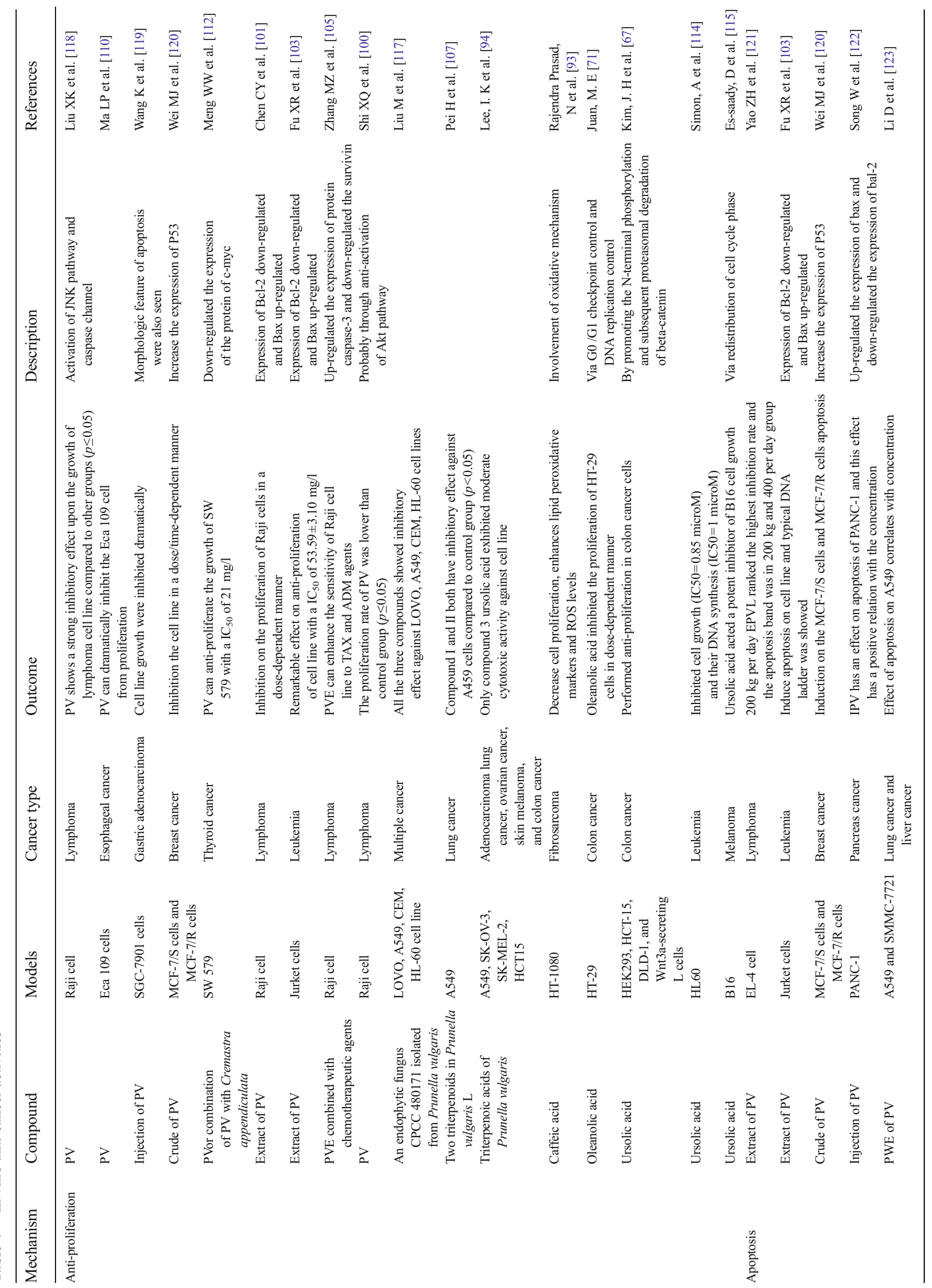




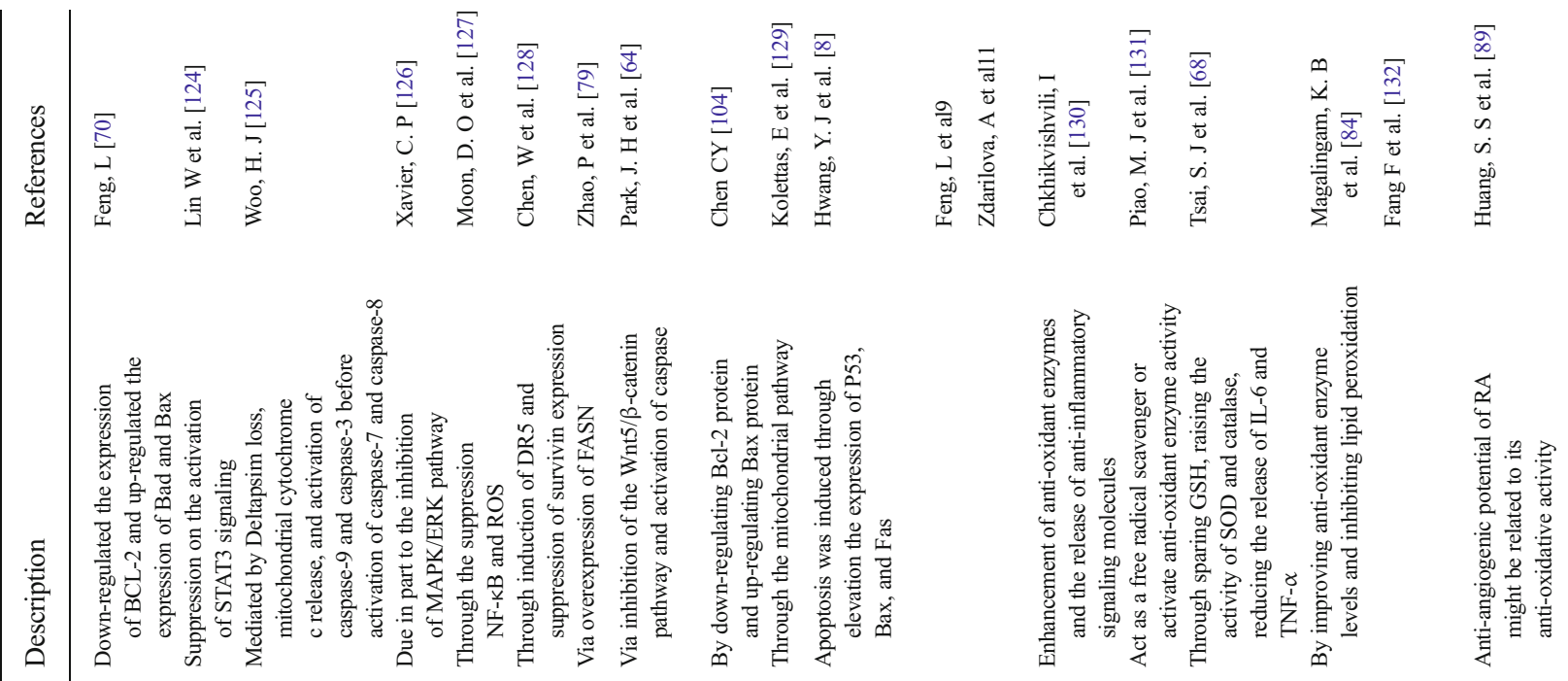

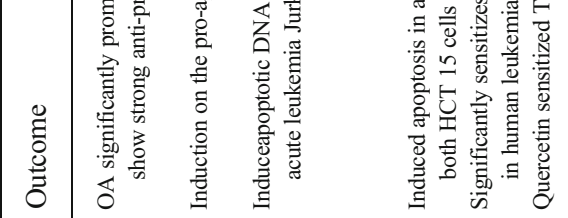
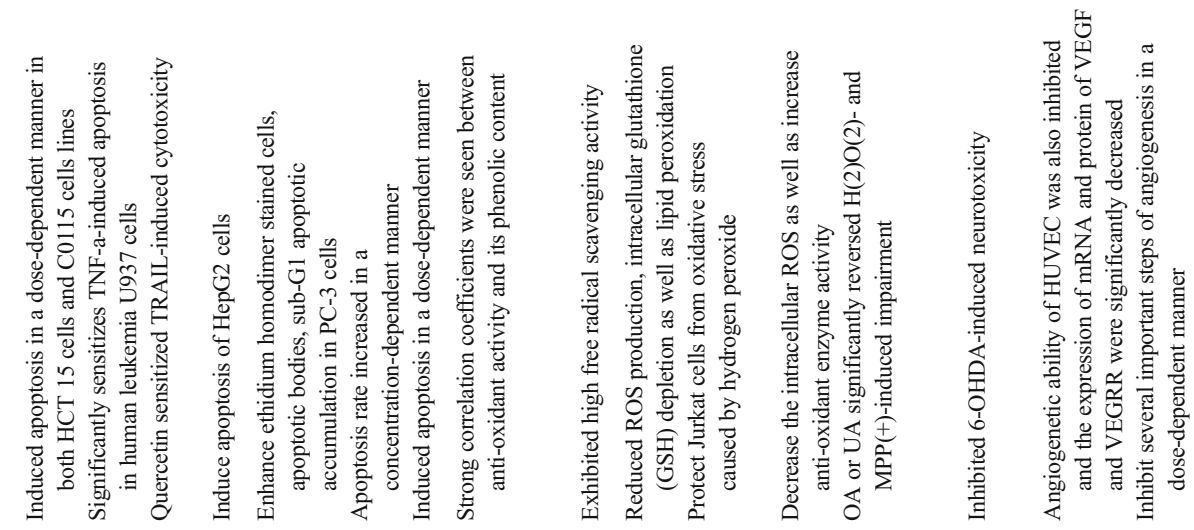

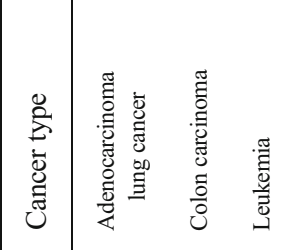
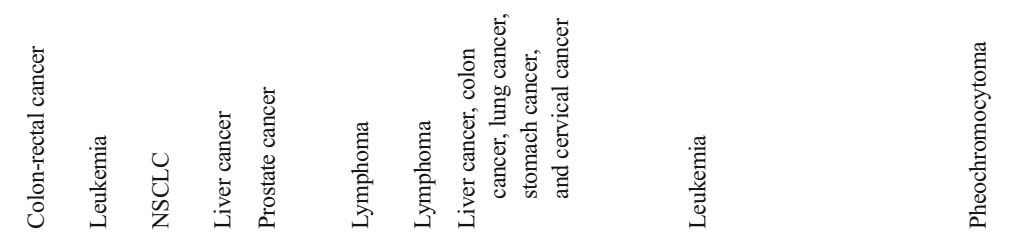

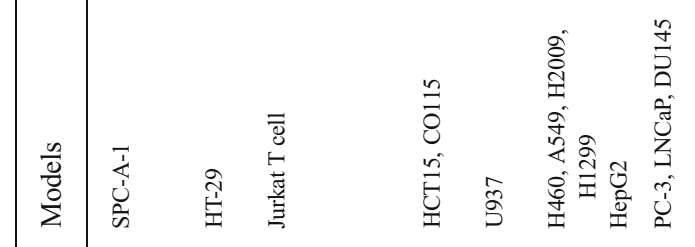

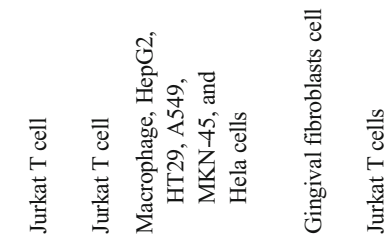

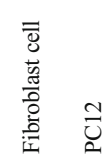

品

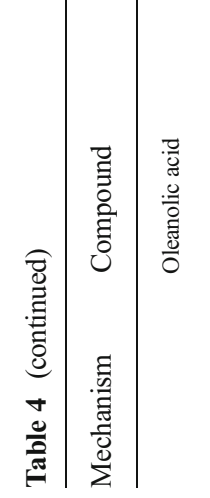

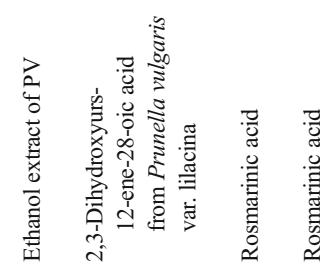
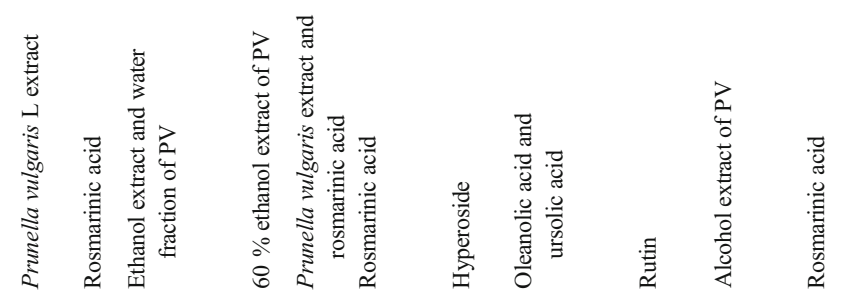


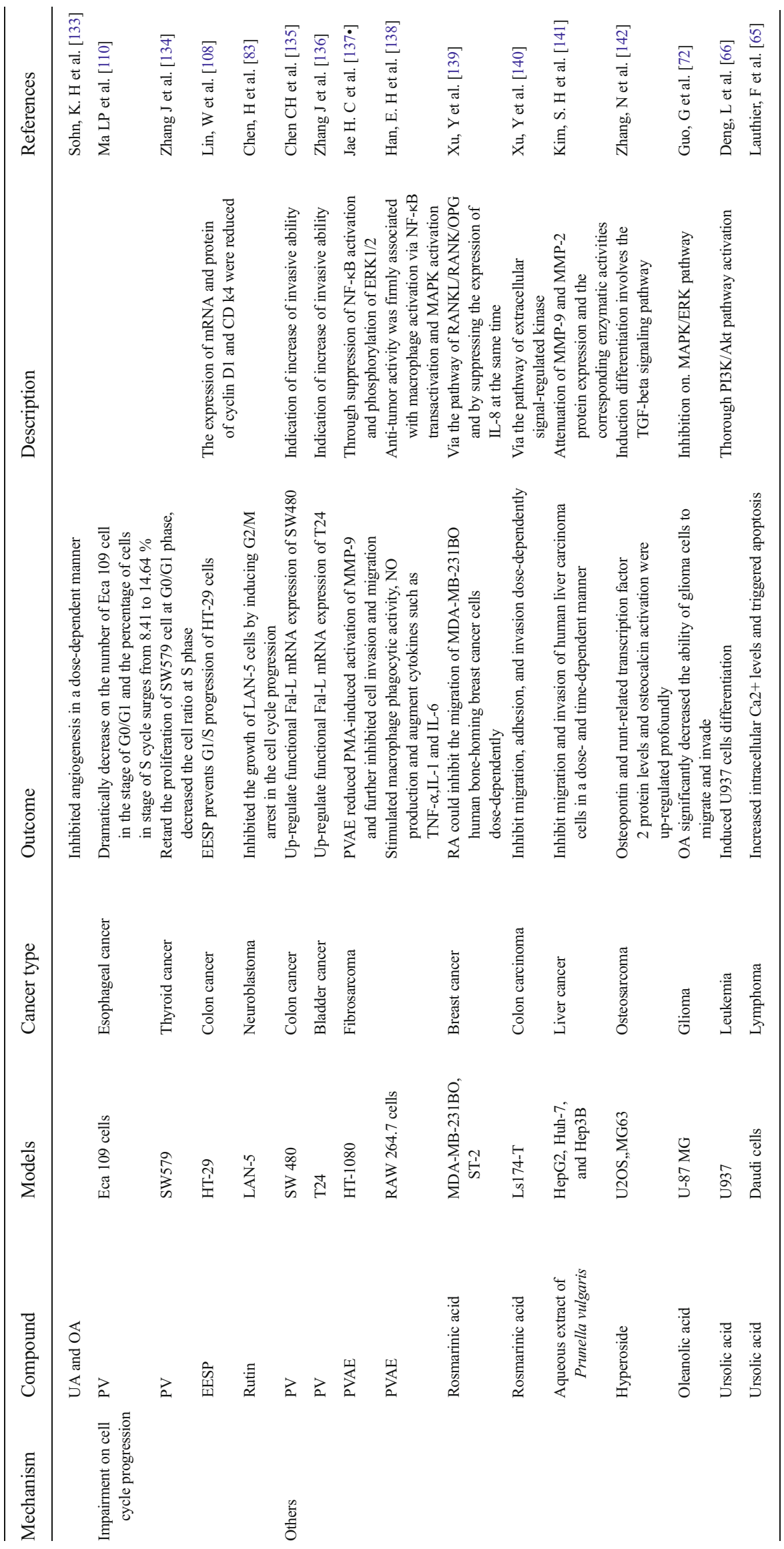


$[64,118]$, and caspase 9 [64] as well as down-regulation of the expression of c-myc [119], Bcl-2 [64, 70, 101, 104, 121, 122, 149], Mcl [64], and Bcl-xl [64]. Other mechanisms have been suggested are the inhibition of mitogen-activated protein kinase/extracellular signal-regulated kinase (MAPK/ERK) pathway [126], the mitochondrial pathway $[150,151]$, the nuclear transcription factor NF-kB [127] pathway, and the intracellular generation of reactive oxygen species (ROS) $[61,68,77,130,131,152,153]$.

\section{Anti-angiogenesis}

P. vulgaris extracts [154] and rosmarinic acid [89] exhibited a dose-dependent inhibition of in vitro angiogenic properties of endothelial cells, including proliferation, metastasis, adhesion, and tube formation. Inhibition of ROS production was implicated as a potential mechanism for the decreased VEGF expression and decreased interleukin 8 (IL-8) release in response to rosmarinic acid treatment [89]. Triterpene acids [133], ursolic acid, and oleanolic acid, have been shown to inhibit angiogenesis in a dose-dependent manner in the chick chorioallantoic membrane (CAM) assay. Both ursolic acid and oleanic acid inhibited the proliferation of bovine arotic endothelial cells [133]. Jae $\mathrm{HC}$ et al. [137•] found that aqueous extract of $P$. vulgaris inhibited tumor angiogenesis and metastasis through suppression of NF- $\mathrm{KB}$ activation and phosphorylation of ERK $1 / 2$ by reducing the expression matrix metalloproteinase 9 (MMP-9). Aqueous extract of P. vulgaris, called PVAE [141], inhibited the migration and metastasis of human liver cancer cell lines by inhibiting the enzymatic activity and protein expression of MMP-2 and MMP-9.

\section{In Vivo Anti-cancer Activity (Table 5)}

P. vulgaris has been characterized for its in vivo anti-cancer effects in multiple animal models (Table 5). Using Lewis lung carcinoma model, $P$. vulgaris [155•] has shown a significant anti-tumor effect when compared with control group. Using a human colon carcinoma HT-90 cell xenograft athymic nude mouse model [124], ethanol extract of $P$. vulgaris (also called EESP) significantly reduced tumor load when compared to control group without any signs of toxicity. In a T cell lymphoma EL-4 cell transplanted C57BL/6 mice model [20], ethanol extract of $P$. vulgaris inhibited tumor growth. In a benzo(a)pyrene intraperitoneal (i.p) injected $\mathrm{A} / \mathrm{J}$ mice model [21], ethanol extract of $P$. vulgaris inhibited lung tumor multiplicity by more than $90 \%$; rosmarinic acid, a key component of $P$. vulgaris, has been shown to inhibit skin and colon carcinogenesis in a DMBA-induced skin carcinogenesis Swiss albino mice model [140] and in a rat model of colon carcinogenesis [92], respectively.

\section{Clinical Studies (Table 6)}

Table 6 summarized clinical studies reported for P. vulgaris. Zhang et al. [157••] reported a randomized clinical trial (RCT) in which 101 patients with non-Hodgkin's lymphoma were divided into three groups: EPVL (extract of P. vulgaris), CHOP (combined chemotherapy regimen), and EPVL + CHOP. CHOP consists of (C)yclophosphamide, $(\mathrm{H}) y d r o x y d a u n o r u b i c i n,(\mathrm{O})$ ncovin (vincristine), and (P)rednisone or (P)rednisolone. A $70 \%$ curative efficacy were observed in the combination group $(\mathrm{EPVL}+\mathrm{CHOP})$ comparing with $52.6 \%$ in the chemotherapy group (CHOP) and $10.5 \%$ in P. vulgaris alone (EPVL) group, indicating that $P$. vulgaris may serve as an effective adjuvant treatment with chemotherapy for non-Hodgkin's lymphoma [157••]. Zhou RY [158] reported another randomized clinical trial of 23 late stage liver cancer patients into two groups: treatment group in which P. vulgaris (EESP-ethanol extract of Spica prunella) and a formulated injectable mixture called "anti-inflammation injection formulation \#1" were perfused through liver artery; and control group with cisplatin (DDP), hydroxycamptothecin (HCPT), and 5-fluorouracil (5-FUu) perfused. Although there was no significant difference in the 1-year survival rates between the two groups, there is a significant difference of clinical symptoms with a higher Karnofsky Performance Scale (KPS) index (a higher KPS score indicates less functional impairment) was seen in the $P$. vulgaris group $(p<0.01)$. A similar observation was also seen in another study [159] in which $P$. vulgaris injection showed better results in controlling cancer-associated symptoms and higher KPS scores in patients with late stage gastrointestinal cancer. Zhou et al. $[161 \cdot \bullet$ ] reported the randomization of a group of 52 bronchopulmonary carcinoma patients with moderate or severe hydrothorax into two groups: one group received tube closed drainage along with intrapleural injection of $P$. vulgaris, and the control group received chemotherapy alone. The curative effect rate, average remission period, adverse reaction rate between $P$. vulgaris group, and chemotherapy alone group were 85 vs $46 \%, 7$ vs 1.5 months, and $0 \sim 12 \%$ vs $4 \sim 35 \%$, respectively $(p \leq 0.05)$. This observation is confirmed by another study [160] on using P. vulgaris injection to treat hydrothorax in 78 patients as compared with the chemotherapy alone group. These results suggest that $P$. vulgaris is a potentially non-toxic therapeutic agent for the treatment of hydrothorax caused bronchopulmonary carcinoma.

\section{Conclusion}

P. vulgaris has been extensively used in China both independently and as a part of a multi-modal approach to treat cancer patients with standard chemotherapy. $P$. vulgaris appears to 


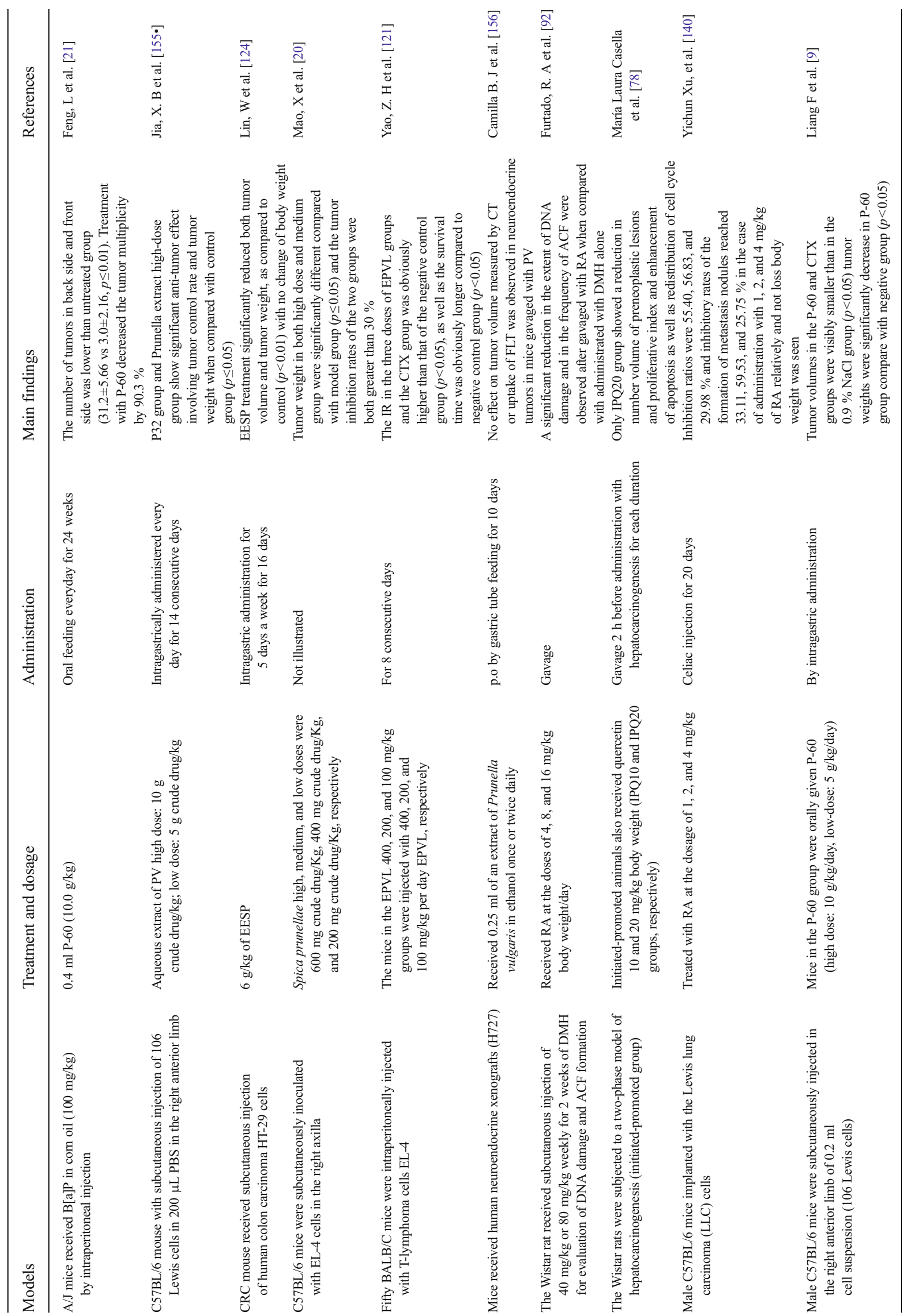




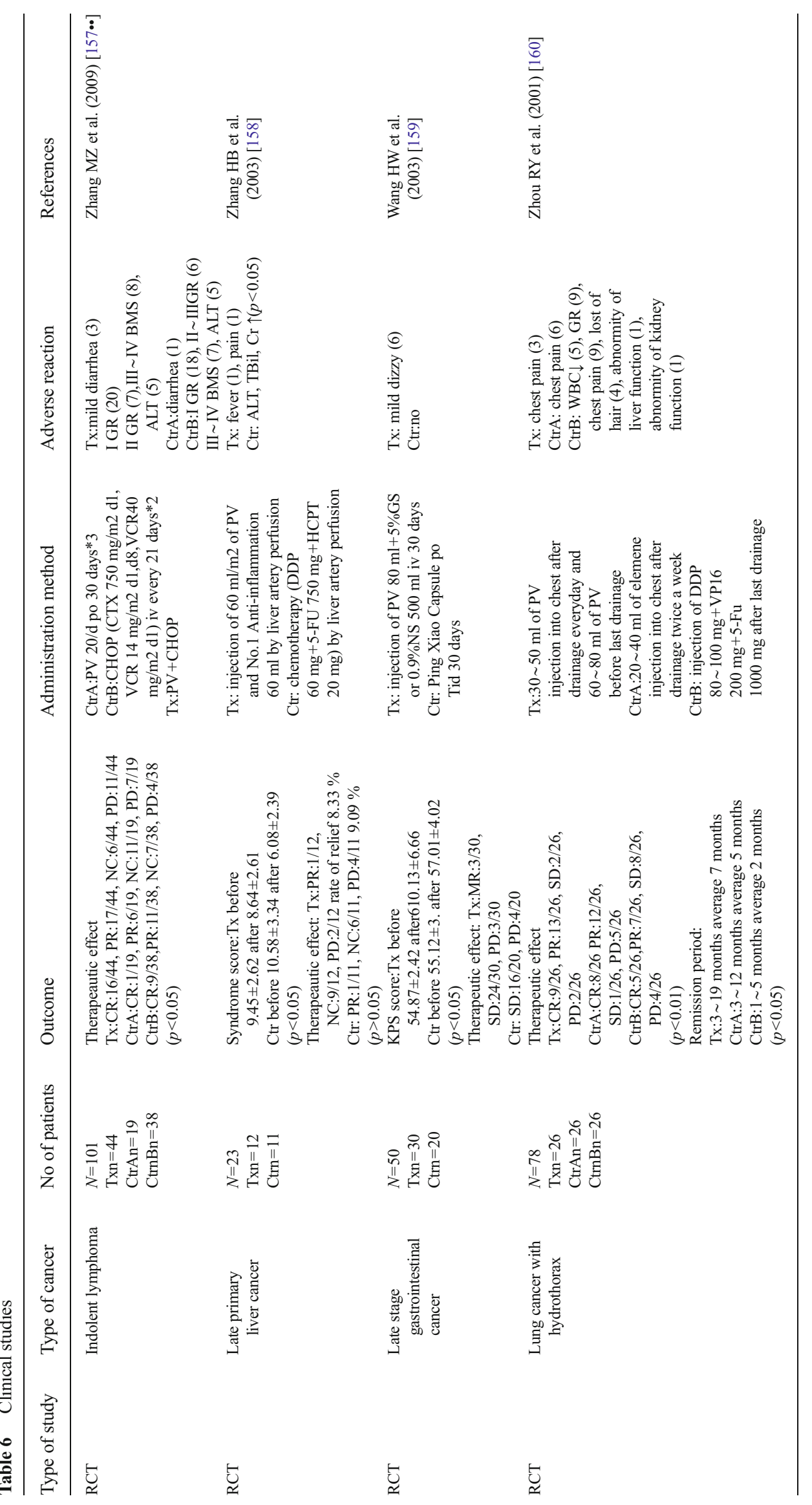


target multiple signaling pathways and has a complex mechanism of action. The complexity of the herb may be a key element of its therapeutic or preventive effectiveness. However, the pleiotropic effects that it causes make determining definitive targets for future pharmaceutical development more challenging. Based on its strong efficay in both pre-clincial model systems and in a number of clinical trials with limited toxicity or adverse effects, further studies should focus on characterizing $P$. vulgaris as a promising cancer chemopreventive agent.

\section{Compliance with Ethics Guidelines}

Conflict of Interest Mofei Huang, Yian Wang, Ling Xu, and Ming You declare that they have no conflict of interest.

Human and Animal Rights and Informed Consent This article does not contain any studies with human or animal subjects performed by any of the authors.

\section{References}

Papers of particular interest, published recently, have been highlighted as:

- Of importance

-• Of major importance

1. Maimon Y, Karaush V, Yaal-Hahoshen N, et al. Effect of Chinese herbal therapy on breast cancer adenocarcinoma cell lines. J Int Med Res. 2010;38(6):2033-9.

2. R. C. The MacDonald encyclopaedia of medicinal plants. Edinburgh: MacDonald Co; 1984.

3. Pinkas M, Trotin F, Peng M. Use, chemistry and pharmacology of the Chinese medicinal plants. Fiotherapia. 1994;55:343-53.

4. Psotova J, Kolar M, Sousek J, Svagera Z, Vicar J, Ulrichova J. Biological activities of Prunella vulgaris extract. Phytother Res: PTR. 2003;17(9):1082-7. This study provides evidences indicating that the organic fraction of Prunella vulgaris have antioxidative, antimicrobial, and antiviral effects which presenting good prospects for the medicinal applications of $P$. vulgaris.

5. Meng G, Zhong KJ, Zhang MZ. Chemical constituents of Prunella vulgaris and its anti-cancer activity. Northwest Pharm J. 2007;22(4):211-3.

6. Oh C, Price J, Brindley MA, et al. Inhibition of HIV-1 infection by aqueous extracts of Prunella vulgaris L. Virol J. 2011;8:188.

7. Brindley MA, Widrlechner MP, McCoy JA, et al. Inhibition of lentivirus replication by aqueous extracts of Prunella vulgaris. Virol J. 2009;6:8.

8. Hwang YJ, Lee EJ, Kim HR, Hwang KA. In vitro antioxidant and anticancer effects of solvent fractions from Prunella vulgaris var lilacina. BMC Complement Alternat Med. 2013;13:310.

9. Feng L, Jia X, Zhu MM, Chen Y, Shi F. Antioxidant activities of total phenols of Prunella vulgaris L. in vitro and in tumor-bearing mice. Molecules (Basel, Switzerland). 2010;15(12):9145-56.

10. Yoon MY, Choi GJ, Choi YH, et al. Effect of polyacetylenic acids from Prunella vulgaris on various plant pathogens. Lett Appl Microbiol. 2010;51(5):511-7.
11. Zdarilova A, Svobodova A, Simanek V, Ulrichova J. Prunella vulgaris extract and rosmarinic acid suppress lipopolysaccharideinduced alteration in human gingival fibroblasts. Toxicol In Vitro Int J Publ Assoc BIBRA. 2009;23(3):386-92.

12. Hwang SM, Lee YJ, Yoon JJ, et al. Prunella vulgaris suppresses HG-induced vascular inflammation via Nrf2/HO-1/eNOS activation. Int J Mol Sci. 2012;13(1):1258-68.

13. Hwang YJ, Lee EJ, Kim HR, Hwang KA. NF-kappaB-targeted anti-inflammatory activity of Prunella vulgaris var. lilacina in macrophages RAW 264.7. Int J Mol Sci. 2013;14(11):21489-503.

14. Cheng Q, Zhang X, Wang O, et al. Anti-diabetic effects of the ethanol extract of a functional formula diet in mice fed with a fructose/fat-rich combination diet. J Sci Food Agric. 2014.

15. Hwang SM, Kim JS, Lee YJ, et al. Anti-diabetic atherosclerosis effect of Prunella vulgaris in $\mathrm{db} / \mathrm{db}$ mice with type 2 diabetes. Am J Chin Med. 2012;40(5):937-51.

16. Collins NH, Lessey EC, DuSell CD, et al. Characterization of antiestrogenic activity of the Chinese herb, prunella vulgaris, using in vitro and in vivo (Mouse Xenograft) models. Biol Reprod. 2009;80(2):375-83.

17. Shin TY, Kim YK, Kim HM. Inhibition of immediate-type allergic reactions by Prunella vulgaris in a murine model. Immunopharmacol Immunotoxicol. 2001;23(3):423-35.

18. Fang X, Chang RC, Yuen WH, Zee SY. Immune modulatory effects of Prunella vulgaris L. Int J Mol Med. 2005;15(3):491-6.

19. Jun MS, Kim HS, Kim YM, et al. Ethanol extract of Prunella vulgaris var. lilacina inhibits HMGB1 release by induction of heme oxygenase- 1 in LPS-activated RAW 264.7 cells and CLP-induced septic mice. Phytother Res: PTR. 2012;26(4): 605-12.

20. Mao X, Wang G, Zhang W, Li S. A study on inhibitory effect of Spica prunellae extract on T lymphoma cell EL-4 tumour. Afr J Tradit Complement Alternat Med AJTCAM / Afr Netw Ethnomed. 2013;10(5):318-24.

21. Feng L, Jia X, Zhu M, Chen Y, Shi F. Chemoprevention by Prunella vulgaris $L$ extract of non-small cell lung cancer via promoting apoptosis and regulating the cell cycle. Asian Pac J Cancer Prev: APJCP. 2010;11(5):1355-8.

22. Sun XQ. Treating cancer by cultivation vital qi and elimination stagnation. Tradit Chin Med J. 2010;9(5):17-24.

23. Lin H, Mei QX. Anti-tumor bioactivity of Prunella vulgaris and research progress on its clinical use. Chin Arch Tradit Chin Med. 2010;28(8):1717-8.

24. He XM. 66 cases of treating thyroid tumor using Xiaoliu decoction. CJGMTCM. 2006;21(7):85-6.

25. Cao ZY, Lan L. Experiences of Pro Du Jian in treating digestive tract tumor using combination of Traditional Chinese and Western Medicine. J Fujian Univ TCM. 2011;21(6):51-3.

26. Li DY, Deng XM, Gao ST. 33 cases of treating brain metastasis of NSCLC using combinaiton of Traditional Chinese and Western medicine. TCM Res. 2009;22(7):37-8.

27. Lan L, Cao ZY, Du J. Treating digestive tract tumor using combination of FZYL decoction and chemotherapy. J Fujian Univ TCM. 2014;24(2):43-5.

28. Yan Y, Chou TS, Chen MX. The effects of Fu Zheng Yi Liu Ointment on spleen deficiency syndrome of adjuvant chemotherapy colorectal cancer. Guiding J Tradit Chin Med Pharm. 2014;20(5):26-8.

29. Xiao GS, Dai Z, Song F, Peng XL. Cancer live side joint and oxaliplation into 5-fluorouracil treatment of advanced digestive tumors random parallel controlled study. J Pract Tradit Chin Intern Med. 2014;28(3):116-8.

30. Chen PY, Xu HF, Zhang YH, Zeng FB. Investigation on antitumor effect of Luo Li ointment. Hubei J TCM. 2014;36(04): 19-20. 
31. Chen WJ, Wang B, Han XL. Adjunctive therapy of hypopharyngeal carcinoma by Qing Liu Liang Hou recipe. Chin J Integr Tradit West Med. 2012;32(07):892-5.

32. Wu YQ, Dai XC, Chen W, Hu P. A review on treating brain tumor using traditional Chinese medicine. New Chin Med. 2004;36(8): 76-8.

33. Liu XY, Yang QY, Pan BH. 60 cases of treating intermediate and advanced stage of primary liver cancer using external application of liver cancer pain removal ointment. Henan Tradit Chin Med. 2004;24(9):24-5.

34. Liu HY. Combined chemotherapy and Ping LIu Kang Capsule to treating 47 cases of late lung cancer. Hunan Guilding J TCMP. 2002;8(6):350-4.

35. Jin CS. Clinical observation on the Gui Jiu Shi Cao decoction in treating advanced stage cancer. Mod J Intregr Tradit Chin West Med. 2009;18(27):3296-7.

36. Yang ZJ, Li QF. Review on treating esophageal cancer with traditional Chinese medicine. Inf Tradit Chin Med. 1993;4:16-9.

37. Cao HT, Li FJ, He YM. Current situation of treating pancreatic cancer using traditional Chinese medicine. TCM Res. 2005;18(12):49-53.

38. Hao YX, Zhang DZ, Zhang JW. Review on clinical application of common intervention of Traditonal Chinese Medicine on tumor. World Chin Med. 2006;1(1):58-60.

39. Li XJ, Jia YJ. Analysis of using method of combination of strengthening the body resistance, detoxification and removing blood stasis treating maglinant cancer. Glob Tradit Chin Med. 2013;6(7):534-6.

40. Hu RJ. Experimental study of anti-cancer formula and expression of cancer-related gene. Drug Eval Res. 2010;33(2):139-42.

41. Li PP, Wang NQ, Yang XY, Sun H. Clinial study of treating advanced staged cancer using Yi Qi Xiao Zhen decoction. J Tradit Chin Med. 1994;35(4):217-9.

42. Su XC, Xiao LZ, LIu CB, Yan BC. Clinical observation oe the treatment of 30 cases of nasopharyneal carcinoma infected by EB virus by Pujijian decoction together with radio-chemical method. Guiding J TCM. 2005;11(1):32. 33,36.

43. Han H, Sheng XL, Cui Y. In vivo effect of Bi Yan Qing Du Gradule on nasopharyngeal cancer. Guang Dong Med. 2009;30(9):1244-5.

44. Shu JH, Zhou RY, Zhong Y, Wu LY. Treatment of 45 cases of advanced colorectal cancer with Yi Qi Jie Du Decoction and CapeOX chemotherapy. Shanghai J TCM. 2011;45(5):33-5. 45.

45. Zhao C, Zhang X, Yang PY. Clinical observation of combination of Yi Qi Jie Du Decoction with bronchial artery infusion with chemical drugs in treating advanced NSCLC. J Sichuan Tradit Chin Med. 2012;30(10):85-6.

46. Chen LZ, Jin CF, Chen SY. Treatment of 30 cases of intermediate and advanced pancreatic cancer using Yi Ai San Jie decoction and chemotherapy. J Tradit Chin Med. 2012;53(11):965-6.

47. Gu XX, Liu SL, Tao YH. Clinical observation of 32 cases of treating intermediate and advanced cancer with Yan Shu injection. Jilin J Tradit Chin Med. 2005;25(9):19-20.

48. He JF, Tang Y, He XH, Feng YN. Clinical observation of Xiao Ling Capsule treating lung cancer. Liaoning J Tradit Chin Med. 2005;32(2):91-2.

49. Ma JW, Chen B, Zhi Y, Ma XY. Treating digestive tract magliment tumor using syndrome differentiation of traditional Chinese medicine. J Gen Hosp Air Force PLA. 2005;21(4):225-7.

50. Jia XB, Shi F, Huang Y, Chen Y, Jia SD, Wang XY. Study on in vivo and in vitro anti-tumor effect against lung cancer of San Cao Decoction and its compatibility. Chin Tradit Herb Drugs. 2010;41(4):592-6.

51. Song CS, Guo JP, Zhang R. Observation on effect-enhancing and toxicity -reducing effect of anti-tumor pills on chemotherapy of malignant cancer. Liaoning J Tradit Chin Med. 2001;28(8):487-8
52. Li YH, Gu HH, Huang XW, Lin LZ. Clinial study of effect of Fu Zheng Xiao Liu mixture in treating malignant tumor in middle of advanced stage. Lishizhen Med Mater Med Res. 1999;10(11): 849-50.

53. Shen D, Bao JM, Lv P, Mou CL. Clinial observation of 32 cases of treating intermediate and advanced lung cancer using Fu Zheng Xiao Ji Decoction. Zhe Jiang J Tradit Chin Med. 2007;46(7):5067.

54. Cai GR, Hao YX. Traditional Chinese Medicine on treatment of lung cancer. J China Jpn Friendship Hosp. 1998;12(4):355-8.

55. Wang Y, Yao R, Gao S, et al. Chemopreventive effect of a mixture of Chinese Herbs (antitumor B) on chemically induced oral carcinogenesis. Mol Carcinog. 2013;52(1):49-56.

56. Wang J. Result of phase III clinical trial of Zeng Sheng-Ping in the treatment of patients with esophageal epithelial hyperplasia. China J Oncol. 2000;22(6):510-2.

57. Zhang Z, Wang Y, Yao R, et al. Cancer chemopreventive activity of a mixture of Chinese herbs (antitumor B) in mouse lung tumor models. Oncogene. 2004;23(21):3841-50.

58. Fan X. Inhibitory effect of antitumor-B and retinamide on precancerous lesions of the bladder in rats. Zhongguo Yi Xue Ke Xue Yuan Xue Bao Acta Acad Med Sin. 1993;15(1):71-3.

59. Liu Y, Song SJ. Chemical constituents of Prunalla vulgaris and research on its bilactivity progress. J Shenyang Pharm Univ. 2003;20(1):55-9.

60. Gu XJ, Qian SH, Li YB, Li P. Chemical constituents of Prunella vulgaris and research progress of pharmacological action. Chin Wild Plant Resour. 2007;26(2):5-7.

61. do Nascimento PG, Lemos TL, Bizerra AM, et al. Antibacterial and antioxidant activities of ursolic acid and derivatives. Molecules. 2013;19(1):1317-27.

62. Tu HY, Huang AM, Wei BL, et al. Ursolic acid derivatives induce cell cycle arrest and apoptosis in NTUB1 cells associated with reactive oxygen species. Bioorg Med Chem. 2009;17(20):726574.

63. Ikeda Y, Murakami A, Fujimura Y, et al. Aggregated ursolic acid, a natural triterpenoid, induces IL-1 beta release from murine peritoneal macrophages: role of CD36. J Immunol (Baltimore, Md: 1950). 2007;178(8):4854-64.

64. Park JH, Kwon HY, Sohn EJ, et al. Inhibition of Wnt/beta-catenin signaling mediates ursolic acid-induced apoptosis in $\mathrm{PC}-3$ prostate cancer cells. Pharmacol Rep: PR. 2013;65(5):1366-74.

65. Lauthier F, Taillet L, Trouillas P, Delage C, Simon A. Ursolic acid triggers calcium-dependent apoptosis in human Daudi cells. AntiCancer Drugs. 2000;11(9):737-45.

66. Deng L, Zhang R, Tang F, Li C, Xing YY, Xi T. Ursolic acid induces U937 cells differentiation by PI3K/Akt pathway activation. Chin J Nat Med. 2014;12(1):15-9.

67. Kim JH, Kim YH, Song GY, et al. Ursolic acid and its natural derivative corosolic acid suppress the proliferation of APCmutated colon cancer cells through promotion of beta-catenin degradation. Food Chem Toxicol Int J Published Br Ind Biol Res Assoc. 2014;67:87-95.

68. Tsai SJ, Yin MC. Antioxidative and anti-inflammatory protection of oleanolic acid and ursolic acid in PC12 cells. J Food Sci. 2008;73(7):H174-8.

69. Mallavadhani UV, Vanga NR, Jeengar MK, Naidu VG. Synthesis of novel ring-A fused hybrids of oleanolic acid with capabilities to arrest cell cycle and induce apoptosis in breast cancer cells. Eur J Med Chem. 2014;74:398-404.

70. Feng L, Au-Yeung W, Xu YH, Wang SS, Zhu Q, Xiang P. Oleanolic acid from Prunella Vulgaris L. induces SPC-A-1 cell line apoptosis via regulation of $\mathrm{Bax}$, Bad and $\mathrm{Bcl}-2$ expression. Asian Pac J Cancer Prev: APJCP. 2011;12(2):403-8.

71. Juan ME, Planas JM, Ruiz-Gutierrez V, Daniel H, Wenzel U. Antiproliferative and apoptosis-inducing effects of maslinic and 
oleanolic acids, two pentacyclic triterpenes from olives, on HT-29 colon cancer cells. Br J Nutr. 2008;100(1):36-43.

72. Guo G, Yao W, Zhang Q, Bo Y. Oleanolic acid suppresses migration and invasion of malignant glioma cells by inactivating MAPK/ERK signaling pathway. PLoS One. 2013;8(8):e72079.

73. Chiang EP, Tsai SY, Kuo YH, et al. Caffeic acid derivatives inhibit the growth of colon cancer: involvement of the PI3-K/Akt and AMPK signaling pathways. PLoS One. 2014;9(6):e99631.

74. Wang F, Gao F, Pan S, Zhao S, Xue Y. Luteolin induces apoptosis, G0/G1 cell cycle growth arrest and mitochondrial membrane potential loss in neuroblastoma brain tumor cells. Drug Res. 2014.

75. Qu Q, Qu J, Guo Y, Zhou BT, Zhou HH. Luteolin potentiates the sensitivity of colorectal cancer cell lines to oxaliplatin through the PPARgamma/OCTN2 pathway. Anticancer Drugs. 2014

76. Park HJ, Kim MM. Flavonoids in Ginkgo biloba fallen leaves induce apoptosis through modulation of p53 activation in melanoma cells. Oncol Rep. 2015;33(1):433-8.

77. Danihelova M, Veverka M, Sturdik E, Jantova S. Antioxidant action and cytotoxicity on HeLa and NIH-3T3 cells of new quercetin derivatives. Interdiscip Toxicol. 2013;6(4):209-16.

78. Casella ML, Parody JP, Ceballos MP, et al. Quercetin prevents liver carcinogenesis by inducing cell cycle arrest, decreasing cell proliferation and enhancing apoptosis. Mol Nutr Food Res. 2014;58(2):289-300.

79. Zhao P, Mao JM, Zhang SY, Zhou ZQ, Tan Y, Zhang Y. Quercetin induces HepG2 cell apoptosis by inhibiting fatty acid biosynthesis. Oncol Lett. 2014;8(2):765-9.

80. Deng XH, Song HY, Zhou YF, Yuan GY, Zheng FJ. Effects of quercetin on the proliferation of breast cancer cells and expression of survivin. Exp Ther Med. 2013;6(5):1155-8.

81. Alonso-Castro AJ, Dominguez F, Garcia-Carranca A. Rutin exerts antitumor effects on nude mice bearing SW480 tumor. Arch Med Res. 2013;44(5):346-51.

82. Lin JP, Yang JS, Lu CC, et al. Rutin inhibits the proliferation of murine leukemia WEHI-3 cells in vivo and promotes immune response in vivo. Leuk Res. 2009;33(6):823-8.

83. Chen H, Miao Q, Geng M, et al. Anti-tumor effect of rutin on human neuroblastoma cell lines through inducing G2/M cell cycle arrest and promoting apoptosis. TheScientificWorldJOURNAL. 2013;2013:269165.

84. Magalingam KB, Radhakrishnan A, Haleagrahara N. Rutin, a bioflavonoid antioxidant protects rat pheochromocytoma (PC-12) cells against 6-hydroxydopamine (6-OHDA)-induced neurotoxicity. Int J Mol Med. 2013;32(1):235-40.

85. Hosseinzadeh H, Nassiri-Asl M. Review of the protective effects of rutin on the metabolic function as an important dietary flavonoid. J Endocrinol Investig. 2014.

86. Li FR, Yu FX, Yao ST, Si YH, Zhang W, Gao LL. Hyperin extracted from Manchurian rhododendron leaf induces apoptosis in human endometrial cancer cells through a mitochondrial pathway. Asian Pac J Cancer Prev: APJCP. 2012;13(8):3653-6.

87. Wang T, Zhang JC, Chen Y, Huang F, Yang MS, Xiao PG. Comparison of antioxidative and antitumor activities of six flavonoids from Epimedium koreanum. Zhongguo Zhong Yao Za Zhi Zhongguo Zhongyao Zazhi China J Chin Mater Med. 2007;32(8): 715-8.

88. Sharmila R, Manoharan S. Anti-tumor activity of rosmarinic acid in 7,12-dimethylbenz(a)anthracene (DMBA) induced skin carcinogenesis in Swiss albino mice. Indian J Exp Biol. 2012;50(3): 187-94.

89. Huang SS, Zheng RL. Rosmarinic acid inhibits angiogenesis and its mechanism of action in vitro. Cancer Lett. 2006;239(2):27180.

90. Tai J, Cheung S, Wu M, Hasman D. Antiproliferation effect of Rosemary (Rosmarinus officinalis) on human ovarian cancer cells in vitro. Phytomed Int J Phytother Pytopharmacol. 2012;19(5): 436-43.

91. Yesil-Celiktas O, Sevimli C, Bedir E, Vardar-Sukan F. Inhibitory effects of rosemary extracts, carnosic acid and rosmarinic acid on the growth of various human cancer cell lines. Plant Foods Hum Nutr (Dordrecht, Neth). 2010;65(2):158-63.

92. Furtado RA, Oliveira BR, Silva LR, et al. Chemopreventive effects of rosmarinic acid on rat colon carcinogenesis. Eur J Cancer Prev Off J Eur Cancer Prev Organ (ECP). 2014.

93. Rajendra Prasad N, Karthikeyan A, Karthikeyan S, Reddy BV. Inhibitory effect of caffeic acid on cancer cell proliferation by oxidative mechanism in human HT-1080 fibrosarcoma cell line. Mol Cell Biochem. 2011;349(1-2):11-9.

94. Lee IK, Kim DH, Lee SY, et al. Triterpenoic acids of Prunella vulgaris var lilacina and their cytotoxic activities in vitro. Arch Pharm Res. 2008;31(12):1578-83.

95. Weng H, Tan ZJ, Hu YP, et al. Ursolic acid induces cell cycle arrest and apoptosis of gallbladder carcinoma cells. Cancer Cell Int. 2014;14(96):1-10.

96. Yu Q, Qi J, Wang L, Liu SJ, Yu BY. Pentacyclic triterpenoids from spikes of prunella vulgaris 1 . inhibit glycogen phosphorylase and improve insulin sensitivity in 3T3-L1 adipocytes. Phytother Res: PTR. 2014.

97. Liao L, Guo QS, Liu L, Liu M. Study of flavonoids distribution in various populations of Prunella vulgaris. Zhongguo Zhong Yao Za Zhi Zhongguo Zhongyao Zazhi China J Chin Mater Med. 2008;33(6):651-3.

98. Liu XK, Wang L, Zhang MZ. Involvement of JNK and caspase-3 in human lymphoma cell apoptosis induced by Prunella vulgaris. Zhonghua Yi Xue Za Zhi. 2010;90(10):690-3.

99. Liu XK, Wang L, Zhang MZ. Roles of JNK pathway and inhibition of lymphoma cells by Prunella valgaris. Acad J Second Mil Med Univ. 2010;31(4):452-4.

100. Shi XQ, Lv XQ. Mechanism of inhibition the human lymphoma cell growth by PV. China Pharm. 2008;12(8):1038-40.

101. Chen CY, Wu G, Zhang MZ. Effect of Prunella vulgaris L extract on proliferaton of human Burkitt lymphoma cell line Raji. J Zhengzhou Univ (Med Sci). 2008;43(6):1189-92.

102. Fu XR, Zhang MZ, Liu HM. Effect and mechanism of Prunella vulgaris L extract on proliferation of human Burk itt lymphoma cell line Raji. J Shangdong Med. 2008;48(24):20-3.

103. Fu XR, Zhang MZ, Liu HM. Effect of extract from Prunella Vulgaris on Jurket cell apoptosis. J Zhengzhou Univ (Med Sci). 2008;43(5):964-7.

104. Chen $\mathrm{C}, \mathrm{Wu} \mathrm{G}$, Zhang $\mathrm{M}$. The effects and mechanism of action of Prunella vulgaris 1 extract on Jurkat human T lymphoma cell proliferation. Chin Ger J Clin Oncol. 2009;8(7):426-9.

105. Zhang MZ, Wang XQ. Effects of extract from Prunella vulgaris combined with chemotherapeutic agents on proliferation of lymphoma cells. Tumor. 2009;29(10):961-4.

106. Wang P, Li Z, Fu L, et al. Effects of extracts of Prunella Vulgaris L. on proteome of human lung adenocarcinoma cell line A549. Zhonghua Yi Xue Za Zhi. 2014;94(28):2216-21.

107. Pei HQS. Studies on antitumor activity of two triterpenoids in Prunella vulgaris L. Strait Pharm J. 2011;23(3):43-5.

108. Lin W, Zheng L, Zhuang Q, et al. Spica Prunellae extract inhibits the proliferation of human colon carcinoma cells via the regulation of the cell cycle. Oncol Lett. 2013;6(4):1123-7.

109. Zhang J, Wang Y, Zhao HD. Effects of traditional Chinese medicine Prunella vulgaris on proliferation cycle and apoptosis of human thyroid cancer cell. Prog Mod Biomed. 2011;11(23):4434-6.

110. Ma LP, Zhao PR, Tian AQ. The effect of prunella vulgaris L on Eca 109 cells. J Basic Clin Oncol. 2006;19(3):199-200.

111. Zheng XZ, Zheng XH, Li J. Effect of Prunella vulgaris on cell proliferation and apoptosis of human esophageal cancer Eca-109 cells. Food Nutr China. 2012;18(9):74-6. 
112. Meng WW, Huang XM, Lu DC, Luo ZJ. Prunella vulgaris and crenastra appendiculata anti-proliferate thyroid cancer cell in vitro. China J Mod Med. 2012;22(28):46-50.

113. Liu GY, Luo Q, Xiong B, et al. Tissue array for Tp53, C-myc, CCND1 gene over-expression in different tumors. World J Gastroenterol: WJG. 2008;14(47):7199-207.

114. Simon A, Najid A, Chulia AJ, Delage C, Rigaud M. Inhibition of lipoxygenase activity and HL60 leukemic cell proliferation by ursolic acid isolated from heather flowers (Calluna vulgaris). Biochim Biophys Acta. 1992;1125(1):68-72.

115. Es-saady D, Simon A, Ollier M, Maurizis JC, Chulia AJ, Delage C. Inhibitory effect of ursolic acid on B16 proliferation through cell cycle arrest. Cancer Lett. 1996;106(2):193-7.

116. Es-Saady D, Simon A, Jayat-Vignoles C, Chulia AJ, Delage C. MCF-7 cell cycle arrested at G1 through ursolic acid, and increased reduction of tetrazolium salts. Anticancer Res. 1996;16(1):481-6.

117. Liu M, Hu DJ, Xia X, He JY, Luo MY. Studies on the anti-tumor substances of an endophytic fungus CPCC 480171 isolated from Prunella vulgaris. Pharm Biotechnol. 2008;15(4):262-5.

118. Liu X, Wang L, Zhang M. Involvement of JNK and caspase-3 in human lymphoma cell apoptosis induced by Prenella vulgaris. Natl Med J China. 2010;90(10):690-3.

119. Wang K, Dang HF. The effect of prunella vulgaris on SGC-7901 cells. Shanghai J Med Lab Sci. 2000;15(5):305-7.

120. Wei MJZX, Zhou HS. Study of the effect and mechanism of crude extracts of prunella vulgaris on the breast cancer cells proliferation and anti -drug resistance. J Chin Pharmacol. 2006;23(3):38.

121. Yao ZH, Zhang MZ, Wang LX, Zhao PR. Influence of the extract of Prunella vulgaris L. on in situ apoptosis of mouse T lymphocyte EL-4. Chin J Clin Rehabil. 2006;10(31):126-8.

122. Song W, Zhang BT, Wang YJ. Effect and mechanism of apoptosis of PANC-1 cells by inject of prunella vulgaris. China Foreign Med Treat. 2012;24:26-8.

123. Li D, Jiang S. Research on antitumor effect of PWE of Prunella Vulgaris in vitro. Jilin J Tradit Med. 2009;29(5):434-5.

124. Lin W, Zheng L, Zhuang Q, et al. Spica prunellae promotes cancer cell apoptosis, inhibits cell proliferation and tumor angiogenesis in a mouse model of colorectal cancer via suppression of stat 3 pathway. BMC Complement Alternat Med. 2013;13.

125. Woo HJ, do Jun Y, Lee JY, Woo MH, Yang CH, Kim YH. Apoptogenic activity of 2alpha,3alpha-dihydroxyurs-12-ene-28oic acid from Prunella vulgaris var. lilacina is mediated via mitochondria-dependent activation of caspase cascade regulated by $\mathrm{Bcl}-2$ in human acute leukemia Jurkat T cells. J Ethnopharmacol. 2011;135(3):626-35.

126. Xavier CP, Lima CF, Fernandes-Ferreira M, Pereira-Wilson C. Salvia fruticosa, Salvia officinalis, and rosmarinic acid induce apoptosis and inhibit proliferation of human colorectal cell lines: the role in MAPK/ERK pathway. Nutr Cancer. 2009;61(4):564-71.

127. Moon DO, Kim MO, Lee JD, Choi YH, Kim GY. Rosmarinic acid sensitizes cell death through suppression of TNF-alpha-induced NF-kappaB activation and ROS generation in human leukemia U937 cells. Cancer Lett. 2010;288(2):183-91.

128. Chen W, Wang X, Zhuang J, Zhang L, Lin Y. Induction of death receptor 5 and suppression of survivin contribute to sensitization of TRAIL-induced cytotoxicity by quercetin in non-small cell lung cancer cells. Carcinogenesis. 2007;28(10):2114-21.

129. Kolettas E, Thomas C, Leneti E, et al. Rosmarinic acid failed to suppress hydrogen peroxide-mediated apoptosis but induced apoptosis of Jurkat cells which was suppressed by Bcl-2. Mol Cell Biochem. 2006;285(1-2):111-20.

130. Chkhikvishvili I, Sanikidze T, Gogia N, et al. Rosmarinic acid-rich extracts of summer savory (Satureja hortensis L.) protect Jurkat T cells against oxidative stress. Oxidative Med Cell Longev. 2013;2013:456253.
131. Piao MJ, Kang KA, Zhang R, et al. Hyperoside prevents oxidative damage induced by hydrogen peroxide in lung fibroblast cells via an antioxidant effect. Biochim Biophys Acta. 2008;1780(12): 1448-57.

132. Fang FLW, Zheng LP. Inhibitory effect of alcohol extract of spica prunellae on tumor angiogenesis in vitro. J Fujian Univ TCM. 2011;21(5):18-20.

133. Sohn KH, Lee HY, Chung HY, Young HS, Yi SY, Kim KW. Antiangiogenic activity of triterpene acids. Cancer Lett. 1995;94(2): 213-8.

134. Zhang JWT, Zhao HD. Effects of traditional Chinese medicine Prunella vulgaris on proliferation cycle and apoptosis of human thyroid cancer cell line SW579. Prog Mod Biomed. 2011;11(23): 4434-6.

135. Chen $\mathrm{CH}, \mathrm{Fu} \mathrm{Q}$, Lei YG. Influence of the traditional Chinese medicine Prunella vulgaris on Fas ligand gene expression and invasive ability of human colon cancer cells. Mod Oncol. 2009;17(6):1034-7.

136. Zhang J, Huang J, Cheng F. Influence of traditional Chinese medicine Prunella vulgaris on Fas ligand gene expression and invasive ability of human bladder cancer cell. Prog Mod Biomed. 2010;10(14):2628-31.

137. Choi JH, Han EH, Hwang YP, et al. Suppression of PMA-induced tumor cell invasion and metastasis by aqueous extract isolated from Prunella vulgaris via the inhibition of NF-kappaBdependent MMP-9 expression. Food Chem Toxicol Int J Publ Br Ind Biol Res Assoc. 2010;48(2):564-71. This study found that aqueous extract of Prunella vulgaris inhibited tumor angiogenesis and metastasis through suppression of NF- $K B$ activation and phosphorylation of ERK1/2 by reducing the expression matrix metalloproteinase 9 (MMP-9).

138. Han EH, Choi JH, Hwang YP, et al. Immunostimulatory activity of aqueous extract isolated from Prunella vulgaris. Food Chem Toxicol Int J Publ Br Ind Biol Res Assoc. 2009;47(1):62-9.

139. $\mathrm{Xu} \mathrm{Y,} \mathrm{Jiang} \mathrm{Z,} \mathrm{Ji} \mathrm{G,} \mathrm{Liu} \mathrm{J.} \mathrm{Inhibition} \mathrm{of} \mathrm{bone} \mathrm{metastasis} \mathrm{from}$ breast carcinoma by rosmarinic acid. Planta Med. 2010;76(10): 956-62.

140. Xu Y, Xu G, Liu L, Xu D, Liu J. Anti-invasion effect of rosmarinic acid via the extracellular signal-regulated kinase and oxidationreduction pathway in Ls174-T cells. J Cell Biochem. 2010;111(2):370-9.

141. Kim SH, Huang CY, Tsai CY, Lu SY, Chiu CC, Fang K. The aqueous extract of Prunella vulgaris suppresses cell invasion and migration in human liver cancer cells by attenuating matrix metalloproteinases. Am J Chin Med. 2012;40(3):643-56.

142. Zhang N, Ying MD, Wu YP, et al. Hyperoside, a flavonoid compound, inhibits proliferation and stimulates osteogenic differentiation of human osteosarcoma cells. PLoS One. 2014;9(7):e98973.

143. Richard JB, Paula MT, David JM. Apoptosis, cancer and cancer therapy. Surg Oncol. 1997;6(3):133-42.

144. John FR, Clay MW, Brain VH. Apoptosis, its significance in cancer and cancer therapy. Cancer Biother Radiopharm. 1994;73(8): 2013-26.

145. White E. Life, death and pursuit of apoptosis. Genes Dev. 1996;10:1-15.

146. Rowan S, Fisher DE. Mechanisms of apoptotic cell death. Leukemia. 1997;11:457-65.

147. Goh BH, Chan CK, Kamarudin MN, Abdul Kadir H. Swietenia macrophylla King induces mitochondrial-mediated apoptosis through p53 upregulation in HCT116 colorectal carcinoma cells. J Ethnopharmacol. 2014;153(2):375-85.

148. $\mathrm{Li} \mathrm{C}$, Chen J, Lu B, et al. Molecular switch role of Akt in polygonatum odoratum lectin-induced apoptosis and autophagy in human non-small cell lung cancer A549 cells. PLoS One. 2014;9(7):e101526. 
149. Wu HP, Wang HL, Zhang Z, et al. Analyze on the component of rosmarinic acid in Prunella vulgaris and its effect on alphaglycosidase activity. Zhong Yao Cai Zhongyaocai J Chin Med Mater. 2011;34(11):1712-5.

150. Hur YG, Yun Y, Won J. Rosmarinic acid induces p561ckdependent apoptosis in Jurkat and peripheral T cells via mitochondrial pathway independent from Fas/Fas ligand interaction. J Immunol (Baltimore, Md: 1950). 2004;172(1):79-87.

151. Baek JH, Lee YS, Kang CM, et al. Intracellular Ca2+ release mediates ursolic acid-induced apoptosis in human leukemic HL60 cells. Int J Cancer J Int Cancer. 1997;73(5):725-8.

152. Gorrini C, Harris IS, Mak TW. Modulation of oxidative stress as an anticancer strategy. Nat Rev Drug Discov. 2013;12(12):931-47.

153. Glasauer A, Chandel NS. Targeting antioxidants for cancer therapy. Biochem Pharmacol. 2014.

154. Fan F, Lin W, Zheng LP. Inhibitory effect of alcohol extract of Spica prunellae on tumor angiogenesis in vitro. J Fujian Univ TCM. 2011;21(5):18-20.

155. Feng L, Jia XB, Shi F, Chen Y. Identification of two polysaccharides from Prunella vulgaris L. and evaluation on their anti-lung adenocarcinoma activity. Molecules. 2010;15(8):5093-103. This study has showed, using Lewis lung carcinoma model, Prunella vulgaris has shown a significant anti-tumor effect when compared with control group.

156. Johnbeck CB, Jensen MM, Guan X, et al. Prunella vulgaris does not show effect on CT tumorvolume or FLT uptake in human neuroendocrine xenograft tumors in mice. Mol Imaging Biol. 2012;14:S326.

157.• Zhang MZ, Nan FF, Fu XRBRR, Song M. Efficacy of Prunella vulgaris L. (EPVL) as adjuvant for patients with naive indolent lymphoma. Li Shi Zhen Med Meteria Med Res. 2009;20(3):723-
4. This conducted a randomized clinical trial including $\mathbf{1 0 1}$ patients with non-Hodgkin's lymphoma using Prunella vulgaris. The data indicated that Prunella vulgaris may be used in adjuvant treatment with chemotherapy for nonHodgkin's lymphoma.

158. Zhang HB, Zhou RY. Clinical observation of Spica Prunellae and No.1 anti-inflammation injection in treating late primary liver cancer by liver arterial perfusion. Shanghai J Tradit Chin Med. 2003;37(8):18-20.

159. Wang WH, Zhou RY, Ni AD, Wu LY. Clinical observation of cytokine regulation in late stage gastrointestinal cancer by PVJ, a report of 30 cases. Shanxi J TCM. 2003;19(3):24-6.

160. Zhou RY, Xu ZW, Ni AD. Clinical and experimental observation of hydrothorax in lung cancer cases treated with closed drainage and injection of self heal spike injection. Zhejiang J Integr Tradit Chin West Med. 2001;11(1):5-8.

161.• Zhou RY, Wu LY, Xu ZW, Ni AD. Clinical observation of 26 cases of hydrothorax in bronchopulmonary carcinoma treated with closed drainage and injection of selfheal spike injection. JTCM. 1998;39(11):662-3. This random clinical trial of 52 bronchopulmonary carcinoma patients suggested that Prunella vulgaris is a potentially non-toxic therapeutic agent for the treatment of hydrothorax caused bronchopulmonary carcinoma. This observation is confirmed by the study of reference 116.

162. Zhang YY, Zhang B. 64 cases of treating thyroid tumor using ChaiXiaXiaoYin decoction. Chin J Nat Med. 2003;5(2):93.

163. Shi JG, Wang SH, Wang SW. 66 cases of treating advanced stage mammary cancer using Er Bei Mu Capsule. J Fourth Mil Univ. 2003;24(19):1701-41. 